\title{
Adolescent With Ovarian Immature Teratoma Complicated by Wernicke's Encephalopathy
}

\author{
Christopher Loren Jenks ${ }^{\mathrm{a}, \mathrm{c}}$, Mamatha Mandava ${ }^{\mathrm{b}}$
}

\begin{abstract}
Confusion surrounding the treatment of cancer in the pediatric population can be very daunting especially if one is not a pediatric oncologist. Herein is described a pediatric case of mixed cell ovarian germ cell tumor that was complicated by Wernicke's encephalopathy which improved with standard treatment. This case report highlights the basic treatment plan of mixed cell ovarian germ cell tumor for the general pediatrician as sometimes the general pediatrician can be caught in the midst of a battle between specialists.
\end{abstract}

Keywords: Ovarian; Immature teratoma; Oncology; Thiamine deficiency; Wernicke's encephalopathy

\section{Introduction}

Some confusion may be evident when deciding how to treat an adolescent with ovarian cancer, which is due in part to the rarity of the disease. Ovarian cancer becomes more prevalent with age. We present a case of a 13 year old female with

Manuscript accepted for publication January 19, 2012

\footnotetext{
${ }^{a}$ Department of Pediatrics and Medicine, Section Internal Medicine, Louisiana State University Health Science Center, USA

${ }^{\mathrm{b}}$ Department of Pediatrics, Louisiana State University Health Science Center, USA

${ }^{\mathrm{c} C}$ Corresponding author: Christopher Jenks, Christopher Jenks MD, Box 27, 1501 Kings Hwy, Shreveport, LA 71103, USA.

Email: cjenks@1suhsc.edu
}

mixed cell ovarian germ cell tumor that developed Wernicke's encephalopathy (WE) which improved with treatment.

\section{Case Report}

The patient is a 13 year old white female with no significant past medical history who presented to her pediatrician with decreased appetite, fatigue and weight loss. The patient's physical exam was significant for pallor, a palpable abdominal mass in the left hypochondrium which was firm, and nontender. The patient also had a 50 pound weight loss over the previous 5 weeks. A Computerized tomography (CT) scan showed an abdominal mass (Fig .1).

The laboratory values on admission revealed a white blood cell count of 20.7 with differential of neutrophils $88 \%$, bands $1 \%$, lymphocytes $3 \%$, monocytes $8 \%$, hemoglobin 7.6, hematocrit 24.1, platelets 551, prothrombin time 16.5 , internationalized ratio 1.41 , partial thromboplastin time 38.3 , sodium $136 \mathrm{mmol} / \mathrm{L}$, potassium $3.8 \mathrm{mmol} / \mathrm{L}$, chloride $101 \mathrm{mmol} / \mathrm{L}$, bicarbonate $23 \mathrm{mmol} / \mathrm{L}$, blood urea nitrogen 4 $\mathrm{mg} / \mathrm{dl}$, creatinine $0.4 \mathrm{mg} / \mathrm{dl}$, calcium $8.5 \mathrm{mg} / \mathrm{dl}$, total protein $7.1 \mathrm{~g} / \mathrm{dl}$, albumin $2.4 \mathrm{~g} / \mathrm{dl}$, AST $30 \mathrm{u} / \mathrm{L}$, ALT $12 \mathrm{u} / \mathrm{L}$, alkaline phosphatase $55 \mathrm{u} / \mathrm{L}$.

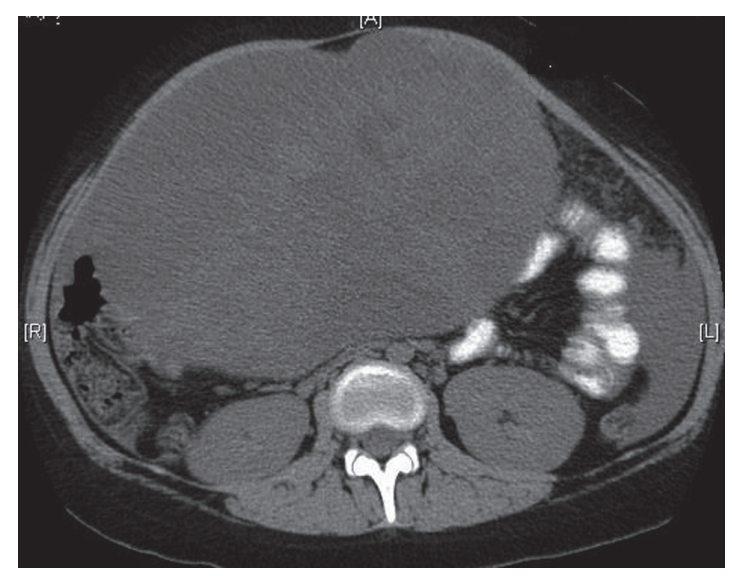

Figure 1. Computerized tomography showing the large ovarian mass. 


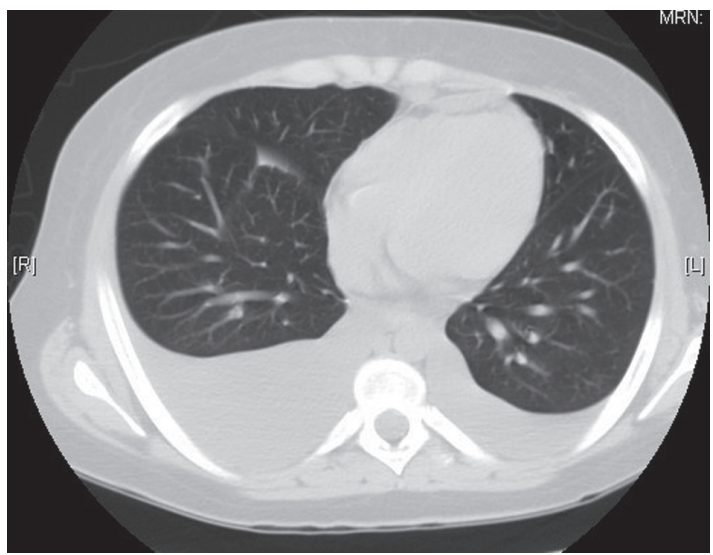

Figure 2. Computerized tomography of the chest showing the bilateral pleural effusions right greater than the left.

Both pediatric oncology and gynecology (OB/GYN) were consulted on admission after which tumor markers were checked showing cancer antigen 125 (CA 125) of 754.5 $\mathrm{u} / \mathrm{ml}$, carcinoembryonic antigen (CEA) of $3.3 \mathrm{ng} / \mathrm{ml}$, Beta human chorionic gonadotropin (Beta hCG) $<1 \mathrm{miU} / \mathrm{ml}$, Lactate dehydrogenase $(\mathrm{LDH}) 381 \mathrm{u} / \mathrm{L}$, and Alpha-fetoprotein (AFP) $95 \mathrm{ng} / \mathrm{ml}$.

Shortly after admission the patient began complaining of dyspnea. A CT of the chest revealed pleural effusions (Fig. 2 ). Thoracentesis was performed showing atypical cells consistent with immature teratoma, some large cells weakly positive for CD30 (possible embryonal carcinoma). The patient also developed acute kidney injury with an increase of serum creatinine of $0.9 \mathrm{mg} / \mathrm{dl}$ to $2 \mathrm{mg} / \mathrm{dl}$.

$\mathrm{OB} / \mathrm{GYN}$ took the patient to surgery and performed a tumor resection with omentectomy and lymph node biopsy which the patient tolerated well. The pathology report revealed a $31 \mathrm{~cm}$ mixed germ cell tumor with focal high grade embryonal carcinoma, free floating nests of immature teratoma (Fig. 3), and no lymph node or vascular involvement.

The day after surgery, the patient developed tingling in hands which rapidly progressed to weakness in all extremities. Workup for this complaint included Magnetic Resonance Imaging (MRI) of the brain and spinal cord which showed swelling of the mammillary bodies consistent with Wernickes Encephalopathy. Electromyography (EMG) revealed peripheral axonal neuropathy. A lumbar puncture (LP) was done with unremarkable findings (glucose $57 \mathrm{mg} /$ $\mathrm{dl}$, protein $42 \mathrm{mg} / \mathrm{dl}$, nucleated cells 0 , RBCs 0 ). Paraneoplastic panel, which includes Anti-Neuronal Nuclear Antibodies (ANNA)-1, ANNA-2, ANNA-3, Purkinje Cell Cytoplasmic Antibodies (PCA)-1, PCA-2, , PCA-TR, Amphiphysin $\mathrm{Ab}$, Collapsin response-mediator protein-5 immunoglobin (CRMP-5), Anit-glial/neuronal nuclear antibody (AGNA)-1 was negative. Other labs included Vitamin B12: $498 \mathrm{pg} / \mathrm{ml}$, folate $2.5 \mathrm{ng} / \mathrm{ml}$, thyroid stimulating hormone (TSH) 1.54 $\mathrm{uiU} / \mathrm{ml}$, antinuclear antibody (ANA) negative, Human Im-

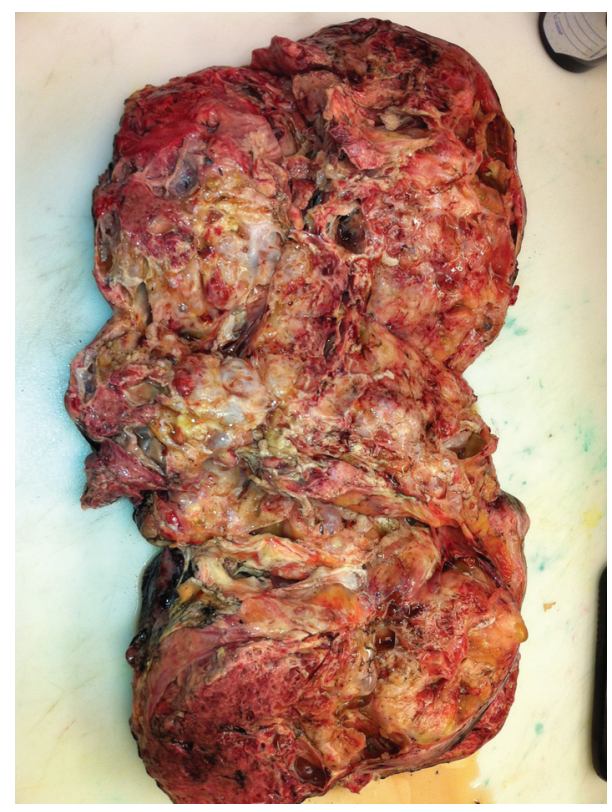

Figure 3. Gross image of the resected tumor.

munodeficiency Virus (HIV) negative, rapid plasma reagin (RPR) negative, Vitamin B6: $3.3 \mathrm{ug} / \mathrm{L}$, iron: $17 \mathrm{ug} / \mathrm{dl}$, TIBC $: 153 \mathrm{ug} / \mathrm{dl}$, transferrin saturation: $11 \%$.

Due to MRI findings and the clinical picture, the patient was started on intravenous thiamine. Within a day the patient showed improvement in her clinical status. The patient's strength improved (from $0 / 5$ to $2 / 5$ all extremities) and the patient had return of sensation in her extremities. Electrocardiogram (EKG) was within normal limits and, echocardiography $(\mathrm{ECHO})$ was obtained to evaluate for cardiomyopathy due to thiamine deficiency (wet beri beri) was unremarkable.

Repeat tumor markers were improved: CA- 125 of 69 $\mathrm{u} / \mathrm{ml}$, AFP $9.0 \mathrm{ng} / \mathrm{ml}$, and CEA $0.8 \mathrm{ng} / \mathrm{ml}$. Chemotherapy regimen included Carboplatin, Etoposide and Bleomycin for 3 days followed by 7 days of granulocyte cell stimulating factor (G-CSF). The patient tolerated first round of chemotherapy well. The patient received a second round of chemotherapy. She tolerated the chemotherapy well and was able to be discharged home, 3 months after re-section the patient is still doing well, tumor markers show AFP $1.3 \mathrm{ng} /$ $\mathrm{ml}$, CA 125: $14.5 \mathrm{u} / \mathrm{ml}$, and CEA $0.7 \mathrm{ng} / \mathrm{ml}$. The patient still remains somewhat weak with strength being $2 / 5$ in the upper extremities.

\section{Discussion}

Germ cell tumors in children are rare. Some would estimate approximately $2.4 / 1,000,000$ children will develop a germ cell tumor. They have the ability to be malignant or benign and do metastasize [1]. The usual sites of metastasis are the central nervous system, the lymphatic system, and the lungs 


\section{[1].}

The main histological classification of germ cell tumors in children is mature teratoma, immature teratoma, and malignant germ cell tumor. The types of malignant germ cell tumors are seminoma, dysgerminoma, yolk sac tumor, choriocarcinoma, embryonal carcinoma, and mixed germ cell tumors [2].

A mixed germ cell tumor has at least 2 different types of tumor with germ cell elements that are mixed together. The different types of germ cell elements that can be present include yolk sac tumour, followed by immature teratoma, embryonal carcinoma, dysgerminoma and mature teratoma. The treatment of the mixed germ cell tumor is multidisciplinary. The primary treatment is surgical resection followed by chemotherapy usually platinum-based regimens [2-6]. Many years ago these tumors were sometimes treated primarily with methotrexate, dactinomycin, cyclophosphamide; however, this has fallen out of favor as many patients would progress on this therapy [3, 4$]$.

There appears to be several staging systems available. Most have similar elements for the staging but seem to subdivide the different stages. For the purposes of this paper the following staging system will be used. Stage I: Localized disease completely resected without microscopic disease [2]. Stage II: Microscopic residual disease, capsular invasion, or microscopic lymph node involvement [2]. Stage III: Gross residual disease, gross lymph node involvement $(>2 \mathrm{~cm})$, or cytologic evidence of tumor cells in ascites [2]. Stage IV: Disseminated disease involving lungs, liver, brain, or bone [2].

In this patient, the most difficult part was obtaining consensus between the specialists. The pediatric oncologist wanted resection prior to chemotherapy. The OB/GYN physicians wanted chemotherapy prior to resection. The national cancer institute has some general guidelines which should help clinicians in the future to help decide which type of treatment should be used for the germ cell tumors. Patients with stage I disease should undergo surgery (unilateral salpingo-oophorectomy) [5]. Most patients undergo post-op chemotherapy (except dysgerminoma and low-grade (grade I) immature teratoma). Observation for stage I is also reasonable. For stage II disease, the patient should undergo surgery (unilateral salpingo-oophorectomy) [5] followed by chemotherapy with BEP (cisplatin, etoposide, and bleomycin) and VAC (vincristine, dactinomycin, and cyclophosphamide ) as salvage therapy [2, 6-10]. A second look laparotomy is usually not helpful except in the instances of a sub-total resection, evidence of residual tumor via radiography, or teratomatous elements in the primary tumor $[2,8,11]$. Stage III disease, the patient should undergo surgery (abdominal hysterectomy and bilateral salpingo-oophorectomy is recommended, or unilateral salpingo-oophorectomy if preservation of fertility is desired) $[5,11]$ According to some authors, if the tumor is very large then three to four courses of chemotherapy may be required prior to debulking surgery [2, 6-8, 12]. Again second look surgery does not appear to be beneficial except in the same cases as stage II [2, 8, 12]. Stage IV disease, the patient should undergo surgery with abdominal hysterectomy and bilateral salpingo-oophorectomy [2]. Again if the tumor is large then consider chemotherapy first. The same rules apply as stage III in considering the second look surgery option $[2,7]$.

\section{Conclusion}

In the end, the decision was made to have our patient undergo resection first followed by adjunctive chemotherapy. The patient developed wernicke's encephalopathy and neuropathy acutely post-op due to thiamin deficiency and stress, but the condition quickly reverted with therapy. The tumor markers decreased markedly after the resection and the chemotherapy. All stages of ovarian germ cell tumor require resection with most physicians opting for post-op adjuvant chemotherapy. In some instances, treatment with chemotherapy prior to resection is reasonable. More research is needed to help delineate the best course of action in the treatment of ovarian cancer.

\section{Abbreviations}

Computerized tomography (CT), Magnetic resonance imaging (MRI), Obstetrics and gynecology (OB/GYN), Electromyography (EMG), lumbar puncture (LP), Anti-Neuronal Nuclear Antibodies (ANNA), Purkinje Cell Cytoplasmic Antibodies (PCA), Collapsin response-mediator protein-5 immunoglobin (CRMP-5), Anit-glial/neuronal nuclear antibiody (AGNA), antinuclear antibody (ANA), Human Immunodeficiency Virus (HIV), rapid plasma reagin (RPR), Electrocardiogram (EKG), echocardiography (ECHO), granulocyte cell stimulating factor (G-CSF), BEP (cisplatin, etoposide, and bleomycin), VAC (vincristine, dactinomycin, and cyclophosphamide).

\section{Financial Disclosure}

None to declare.

\section{Conflict of Interest}

None to disclose.

\section{Author Contributions}

Both authors contributed equally to the case write up, overall 
design and content of the discussion.

\section{References}

1. Lucile Packard Children's Hospital website section on germ cell tumors, accessed 2011. http://www.lpch.org/ DiseaseHealthInfo/HealthLibrary/oncology/gct.html.

2. NCI website section on the germ cell tumors, accessed 2011. http://www.cancer.gov/cancertopics/pdq/treatment/extracranial-germ- cell/HealthProfessional/page2.

3. Zuntova A, Sumerauer D, Teslik L, Kabickova E, Koutecky J. [Mixed germ cell tumours of the ovary in childhood and adolescence]. Cesk Patol. 2004;40(3):92101.

4. Gershenson DM. Chemotherapy of ovarian germ cell tumors and sex cord stromal tumors. Semin Surg Oncol. 1994;10(4):290-298.

5. Low JJ, Perrin LC, Crandon AJ, Hacker NF. Conservative surgery to preserve ovarian function in patients with malignant ovarian germ cell tumors. A review of 74 cases. Cancer. 2000;89(2):391-398.

6. Gershenson DM, Morris M, Cangir A, Kavanagh JJ, Stringer CA, Edwards CL, Silva EG, et al. Treatment of malignant germ cell tumors of the ovary with bleomycin, etoposide, and cisplatin. J Clin Oncol. 1990;8(4):715720.

7. Williams SD, Blessing JA, Moore DH, Homesley HD,
Adcock L. Cisplatin, vinblastine, and bleomycin in advanced and recurrent ovarian germ-cell tumors. A trial of the Gynecologic Oncology Group. Ann Intern Med. 1989;111(1):22-27.

8. Williams SD, Blessing JA, DiSaia PJ, Major FJ, Ball HG, 3rd, Liao SY. Second-look laparotomy in ovarian germ cell tumors: the gynecologic oncology group experience. Gynecol Oncol. 1994;52(3):287-291.

9. American Cancer Society's website section on germ cell tumors, accessed 2011. http://www.cancer.org/Cancer/ OvarianCancer/DetailedGuide/ovarian-cancer-treatinggerm-cell-tumors

10. Rogers PC, Olson TA, Cullen JW, Billmire DF, Marina N, Rescorla F, Davis MM, et al. Treatment of children and adolescents with stage II testicular and stages I and II ovarian malignant germ cell tumors: A Pediatric Intergroup Study--Pediatric Oncology Group 9048 and Children's Cancer Group 8891. J Clin Oncol. 2004;22(17):3563-3569.

11. Peccatori F, Bonazzi C, Chiari S, Landoni F, Colombo $\mathrm{N}$, Mangioni C. Surgical management of malignant ovarian germ-cell tumors: 10 years' experience of 129 patients. Obstet Gynecol. 1995;86(3):367-372.

12. Culine S, Lhomme C, Michel G, Leclere J, Duvillard P, Droz JP. Is there a role for second-look laparotomy in the management of malignant germ cell tumors of the ovary? Experience at Institut Gustave Roussy. J Surg Oncol. 1996;62(1):40-45. 